\title{
A case report of familial combined hypercholesterolemia
}

\section{Bindumalyam Venkatesh Vaishnavi, Anjan Kumar Patra, Bittanakurike Narasappa Raghavendra}

Department of Dermatology, MVJ Medical College and Research hospital, Bangalore, India

Corresponding author: Dr. Bindumalyam Venkatesh Vaishnavi, E-mail: yshnave.bv@gmail.com

\begin{abstract}
Xanthomas are the characteristic cutaneous presentation in hyperlipoproteinemias. Familial combined hyperlipoproteinemia/type II b presents with high plasma cholesterol, high plasma low density lipoprotein (LDL) cholesterol, moderately high plasma triglycerides. Cutaneous findings include tendinous, tuberous and intertriginous xanthomas and xanthelasma palpebrarum. A 5 year old boy presented with multiple yellowish lesions over the joints, gluteal cleft, popliteal fossa. Family history of second degree consanguinity was present with hyperlipidaemia in father, mother and brother. Early diagnosis and treatment mitigate the excess risk of premature atherosclerotic cardiovascular disease that occurs with familial hypercholesterolemia.
\end{abstract}

Key words: Familial combined hypercholesterolemia; Hyperlipidaemias; Xanthoma

\section{INTRODUCTION}

Familial combined hypercholesterolemia is an autosomal dominant disorder characterized by increase in LDL, VLDL, TG levels. The primary defect is a reduction in LDL receptors and increased apoB lipoprotein. Xanthomas are not frequently seen, but can present with tendon, tuberous and plane xanthomas.

\section{CASE REPORT}

A 5 year old male child was brought by his mother with complaints of multiple yellowish to skin coloured lesions present over the joints since 2 years, which progressed to involve other sites. There was no history of pain over the lesions, trauma, weight gain, hoarseness of voice, intolerance to cold, lethargy, chest pain, easy fatigability, breathlessness.

Family history of second degree consanguinity was present with hyperlipidaemia in father, mother and brother. Mother additionally had xanthelasma.

\section{On Examination}

Cutaneous - Multiple yellowish to skin coloured, firm, mobile, non-tender, lobulated plaques were present over both knee and ankle joints.(figure-1). Single skin coloured nodule was present on each elbow joint, base of right great toe (Fig. 1). Skin coloured to yellowish plaque was present over the gluteal cleft, popliteal fossa (Fig. 2). Arcus juvenalis was present in the eyes (Fig. 3). Oral cavity, hair and mucosa were normal.

\section{Investigations}

Routine investigations including blood counts, blood sugar, chest X-ray, thyroid profile, liver and renal function tests were within normal limits [Table 1]. ECG and ECHO was normal. Ultrasound of the abdomen was normal. Histopathology of the section studied from skin showed epidermis with marked thinning (Fig. 4a). The dermis predominantly had foamy histiocytes in aggregates and sheets. Touton type of giant cells interspersed with fibroblasts giving a storiform arrangement was observed at places (Fig. 4b).

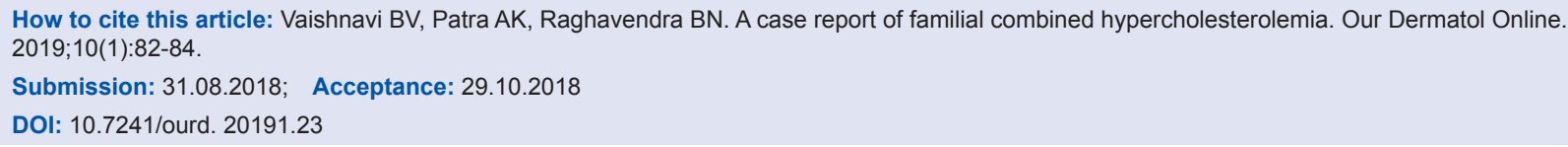




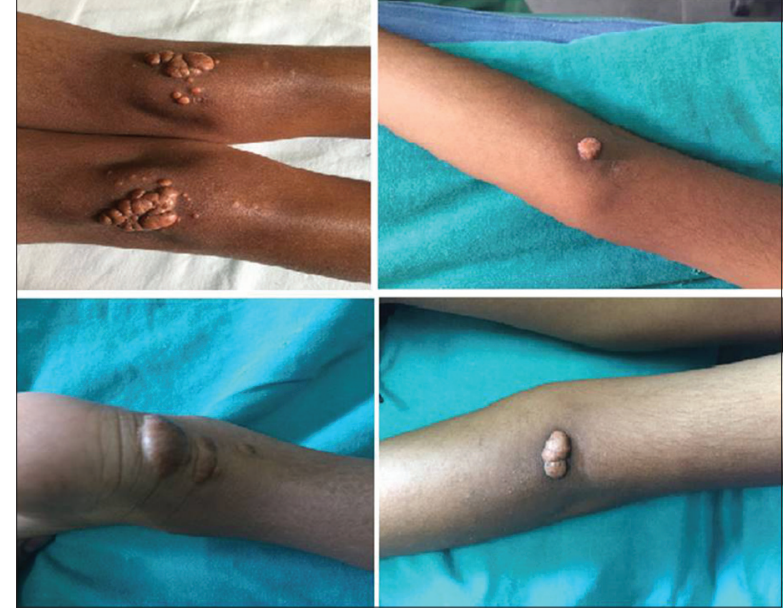

Figure 1: Multiple tuberous xanthomas over knee, elbow and ankle joints.

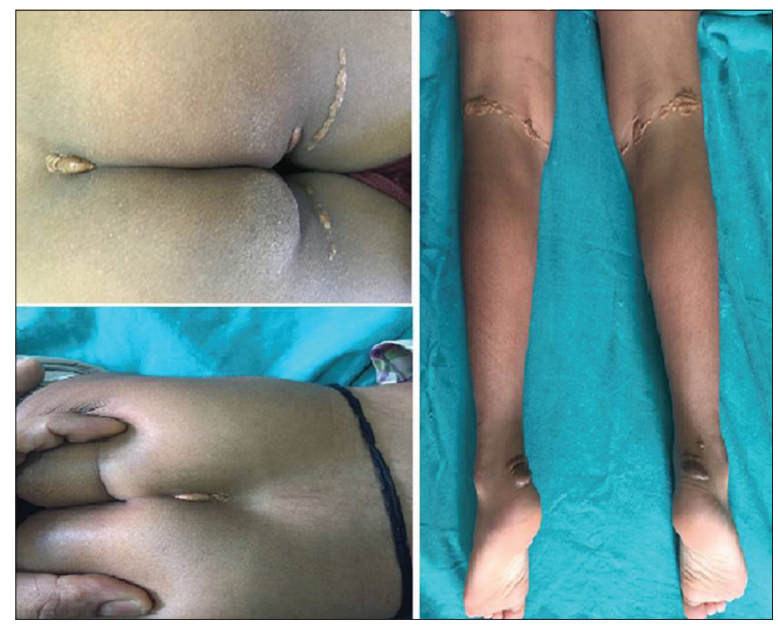

Figure 2: Plane xanthoma over popliteal fossa, gluteal cleft.

Prior to the study, patient gave written consent to the examination and biopsy after having been informed about the procedure.

\section{DISCUSSION}

Disorders of lipid metabolism are heterogeneous. They range from monogenic diseases with high penetrance through polygenic disorders.

Circulating lipids are cholesterol, cholesterol esters, triglycerides and phospholipids. They are insoluble and therefore have to be solubilized by combination with proteins like lipoproteins and the proteins they contain are generally called apolipoproteins. The hyperlipoproteinemias are disturbances of lipid transport of cholesterol and triglycerides through plasma [1].

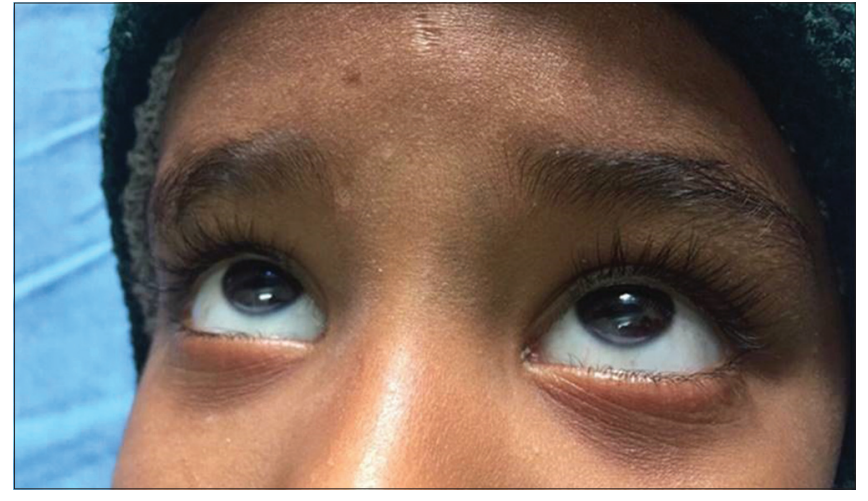

Figure 3: Arcus juvenalis.

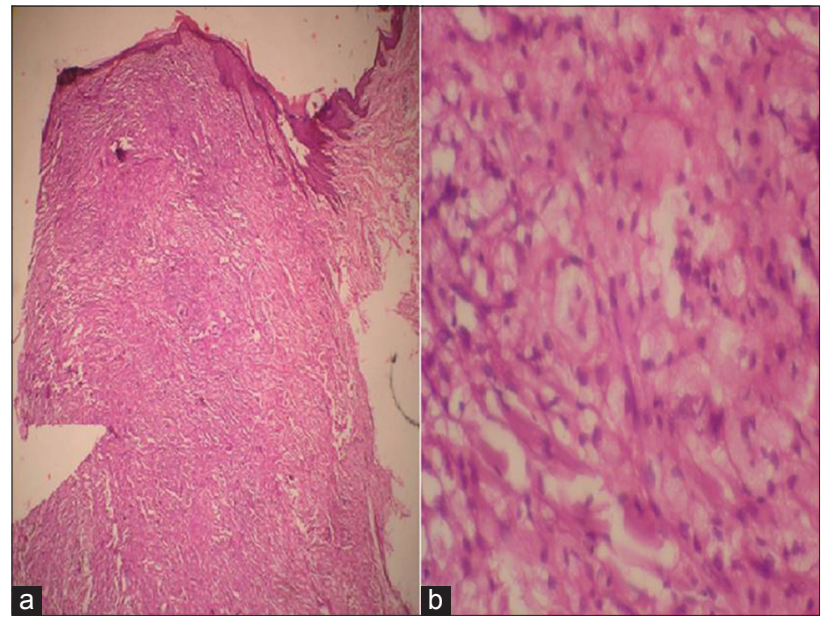

Figure 4: (a) Epidermis and Dermis and (b) showing foamy histiocytes in aggregates and sheets. Touton type of giant cells.

They are classified as WHO/Fredrickson's classification of hyperlipoproteinemia/hyperlipidemia [2]:

Type Lipoprotein abnormality

I Hyperchylomicronemia

IIa Elevated LDL (familial hypercholesterolemia)

IIb Elevated LDL and VLDL (familial combined hypercholesterolemia)

III Broad $\beta$-VLDL (familial dysbetalipoproteinemia)

IV Elevated VLDL (familial hypertriglyceridemia)

$\mathrm{V}$ Elevated chylomicrons and VLDL (mixed hyperlipidemia)

Xanthomatas are commonly caused by a disturbance of lipoprotein metabolism [3]. They can be tuberous, tendinous, eruptive, plane (palmar, intertriginous, diffuse, xanthelasma), others (corneal arcus, tonsillar) $[4,5]$.

Familial combined hypercholesterolemia is characterized by the finding of hypercholesterolemia and hypertriglyceridemia within the same kindred 
Table 1: Fasting lipid profile of family members

\begin{tabular}{lccccc}
\hline Test & Patient $\mathbf{~ m g / d l}$ & Father $\mathbf{~ m g / d l}$ & Mother $\mathbf{~ m g / d l}$ & Brother $\mathbf{~ m g / d l}$ & Normal range \\
\hline Triglycerides & 196 & 663 & 222 & 179 & Up to $150 \mathrm{mg} / \mathrm{dl}$ \\
Total cholesterol & 1045 & 358 & 284 & 316 & Up to 200 $\mathrm{mg} / \mathrm{dl}$ \\
HDL cholesterol & 25 & 52 & 40 & 31 & $30-60 \mathrm{mg} / \mathrm{dl}$ \\
LDL cholesterol & 969 & 215 & 174 & 249 & Up to $100 \mathrm{mg} / \mathrm{dl}$ \\
VLDL cholesterol & 39 & 38 & 44 & 36 & Up to 20 mg/dl \\
\hline
\end{tabular}

and with-kindred members having either one of these abnormalities or both. Patients of familial combined hyperlipoproteinemia type II b present with high plasma cholesterol, high plasma low density lipoprotein (LDL), moderately high plasma triglycerides, tendinous, tuberous and intertriginous xanthomas and xanthelasma palpebrarum [3].

A diet low in cholesterol and saturated fats and high in polyunsaturated fats is recommended. Drugs like gemfibrozil, clofibrate are the first choice. Statins may also be used $[4,6]$.

\section{CONCLUSION}

This case is being presented to highlight the rarity of tuberous, tendon, arcus juvenalis, plane xanthoma with familial combined hypercholesterolemia.

\section{Consent}

The examination of the patient was conducted according to the Declaration of Helsinki principles.

\section{REFERENCES}

1. Flynn PD. Xanthomas and abnormalities of lipid metabolism and storage. In: Burns T, Breathnach S, Cox N, Griffiths C, editors. Rook's Textbook of Dermatology. $8^{\text {th }}$ ed. Oxford: Blackwell Science; 2010. p. 59.81-59.103.

2. Pai VV, Shukla P, Bhobe M. Combined planar and eruptive xanthoma in a patient with type lla hyperlipoproteinemia. Indian J Dermatol Venereol Leprol. 2014;80:467-70.

3. Bhagwat PV, Tophakhane RS, Kudligi C, Noronha TM, Thirunavukkarasu A. Familial combined hypercholesterolemia type II b presenting with tuberous xanthoma, tendinous xanthoma and pityriasis rubra pilaris-like lesions. Indian J Dermatol Venereol Leprol. 2010;76:293-6.

4. Goldsmith LA, Katz SI, Gilchrest BA, Paller AS, Hamlin, Leffell DJ, Wolff K. Xanthomatoses and Lipoprotein disorders. Fitzpatrick's Dermatology in General Medicine. $8^{\text {th }}$ edition. Mc Graw Hill companies: 2012;1600-12.

5. Hilal Ayvaz H, Çelik G, Gönül M, Kılıç A, Özcan N, Çolak A. A case of adult onset disseminated juvenile xanthogranuloma. Our Dermatol Online. 2016;7:66-8.

6. Elsy B, Khan AA, Maheshwari V. Effect of vitamin E isoforms on the primary intention skin wound healing of diabetic rats. Our Dermatol Online. 2017;8:369-75.

Copyright by Bindumalyam Venkatesh Vaishnavi, et al. This is an open-access article distributed under the terms of the Creative Commons Attribution License, which permits unrestricted use, distribution, and reproduction in any medium, provided the original author and source are credited.

Source of Support: Nil, Conflict of Interest: None declared. 